\title{
Implementation Of Clean and Healthy Living Behavior Efforts to Prevent the Spread Of Covid-19 Padang Sambian Kelod Village
}

\author{
Adek Ika Elsiani ${ }^{1, a)}$, I Gusti Ngurah Widya Hadi Saputra ${ }^{2, b)}$, and A.A.N Oka \\ Suryadinatha Gorda ${ }^{3, c}$ )
}

\author{
Economics and Business Faculty, Universitas Pendidikan Nasional, Denpasar, Indonesia \\ Corresponding author : a)ikaelsiani24@gmail.com \\ b)hadisaputra@undiknas.ac.id \\ c)okagorda@gmail.com
}

\begin{abstract}
COVID-19 is a disease caused by a new type of coronavirus (SARS-CoV-2), which has now become a global health problem that can cause respiratory system disorders, ranging from mild symptoms such as flu to lung infections. The most effective effort currently being made is to create community awareness starting from the household level, namely through the implementation of Clean and Healthy Life Behavior (PHBS). PHBS culture is very influential in preventing the transmission of the COVID-19 virus. Through this KKN activity, it will be practiced as well as empowered by the community in implementing PHBS efforts. The data collection technique in this community service activity is in the form of socialization using interview and documentation techniques. This activity is expected to be entrenched in the community so that it can become a new habit that is not only valid during the COVID-19 pandemic but will be sustainable in the order of daily life. Increased community participation in PHBS, where people are able/empowered to make cloth masks to avoid splashing droplets when talking/coughing/sneezing and making natural hand sanitizers made from betel leaf and lime, so that they can suppress/control cases of illness and death due to COVID-19.
\end{abstract}

Keywords: COVID-19, PHBS, Masks, Hand Sanitizer

\section{INTRODUCTION}

COVID-19 is a disease caused by a type of coronavirus new (SARS-CoV-2), which has now become a global health problem that can cause respiratory system disorders, ranging from mild symptoms such as flu to lung infections. Based on data on COVID-19 cases in Bali Province which has increased, it can be said that transmission is still occurring. Therefore, efforts need to be made to be able to control/prevent the spread of the COVID-19 virus to create public awareness starting at the household level through education/socialization in the application of Clean and Healthy Living Behavior (PHBS). The PHBS culture that starts from the household has a great influence in breaking the chain of transmission of COVID-19 (Taringan and Tri. 2020).

PHBS efforts that can be applied are by getting used to washing hands before and after activities. Hand washing is carried out in running water and using soap. It can also be done with an alcohol-based (hand sanitizer) which acts as an antiseptic and always wears a mask. The surface of the object is cleaned using a disinfectant liquid so that the virus does not grow. If you are sick, you should apply cough and sneeze etiquette, which is to stay away from crowds and cover your mouth and nose using a tissue or elbow crease. After that, the tissue is disposed of in a closed trash can. The use of masks is also carried out for people who are sick and healthy, to minimize the spread of the COVID-19 virus. The implementation of PHBS in the community is also able to create a healthy environment and improve the quality of life (Kementerian PUPR RI, 2020).

The implementation of PHBS is highly recommended to all people in Indonesia despite the presence or absence of the Covid-19 outbreak. This is because maintaining the body's immunity is very important so that the body stays healthy and avoids disease. However, there are still many Indonesian people who do not understand the importance of a healthy lifestyle. Especially 
in the community among young people who still need assistance. The implementation of PHBS can be done by making habits such as maintaining a clean environment, exercising regularly, and eating nutritious food. Community empowerment to implement PHBS is very important to do because the first step to starting this habit starts from the household or family (Natsir, 2019). Therefore, the main goal of the PHBS Movement is to improve the quality of health through various things that are the beginning of the contribution of each individual in living a clean and healthy daily life, especially in dealing with the Covid-19 outbreak that is currently happening (Mulyadi, Laras et al. .2020). This community service program in the village of Padang Sambian Kelod aims to create public awareness in preventing the spread of the COVID-19 virus by socializing or educating the implementation of PHBS and developing the potential of villages affected by COVID-19 through training on the application of PHBS at the household level, such as making cloth masks and natural hand sanitizer.

\section{METHOD}

This Community Service method is carried out using educational methods such as understanding and awareness about preventing Covid-19 by designing materials and pamphlets about preventing covid-19 and living clean which will be delivered in socialization activities. Furthermore, conducting field observation methods, to determine the location at the time of socialization. The data collection technique in this community service activity is in the form of socialization using interview and documentation techniques. The interview method used is a free interview method, the interviewer is free to ask the respondent anything, but it must be noted that the question relates to the desired data. If you're not careful, sometimes the question can get out of hand. In general, the purpose of the interview is to obtain accurate information from the informant by submitting certain questions to the informant. The author carried out socialization activities by interviewing and conducting socialization with the people of Padang Sambian Kelod Village about Covid-19.

The author conducts outreach to several people door to door due to the situation and conditions that do not allow the author to gather many people. Documentation is used to collect data and present data. The socialization carried out to the community was socialization about the implementation of PHBS at the household level to prevent the spread of COVID-19 in the family environment and direct practice of making cloth masks to avoid splashing droplets when talking, coughing, and sneezing and making natural hand sanitizers from betel leaf and lime.

\section{RESULTS}

The PHBS program is an effort to provide learning experiences for individuals, groups, and communities by opening lines of communication, providing information and conducting education to increase knowledge, carrying out community empowerment movements so that they can apply healthy ways of living to maintain, maintain, protect, and improve their health.

The general public listens to counseling/education well and there are questions about government policies that are always violated by the community, reasons for keeping a distance which is considered an excessive measure, wearing masks that are good and right, the nature of the virus that causes death and the consequences if violations occur. health protocols if violated. The implementation of this program will be very beneficial for students and the general public in preventing the transmission of Covid-19 and knowing how to carry out the correct health protocol.

Obstacles in this implementation in the conditions of the Covid-19 pandemic which caused limited space to invite people to gather on a large scale, the author conducted outreach to several communities door to door due to situations and conditions that did not allow the author to gather many people. 


\section{DISCUSSION}

\section{Clean and Healthy Living Behavior Healthy (PHBS)}

PHBS stands for Clean and Healthy Behavior. PHBS is a program that has been created by the Indonesian government through the Ministry of Health. The goal is to improve the quality of public health throughout Indonesia. This behavior is an effort so that people run a healthy lifestyle starting from themselves, groups or the wider community. This program was created to raise awareness of the importance of health and implement healthy and clean behavior. The most important benefit of PHBS is the creation of people who are health conscious and have the knowledge and awareness to live a life that maintains cleanliness and meets health standards.

The government has implemented five PHBS arrangements including households, workplaces, schools, health facilities and public places. The household becomes an important point, because the spread of the virus works quickly in that place. A clean and healthy lifestyle has actually been encouraged for a long time, but this habit has only been really implemented since the Covid-19 pandemic occurred

\section{Prevention of the spread of Covid in the community with PHBS}

This disease must be watched out for because of its relatively fast transmission, has a mortality rate that cannot be ignored, and there is no definitive therapy. There are several ways that can be done to be directly involved in efforts to prevent and stop the spread of the corona virus outbreak. New habits for a healthier life must be continuously carried out in society and every individual, so that it becomes a new social norm and individual norm in everyday life. Old habits that are often carried out, such as shaking hands, kissing, kissing hands, crowding / in groups, lazy to wash hands must be abandoned because they support the transmission of Covid-19.

We are required to be able to adapt/adjust new habits wherever we are, such as at home, in the office, at school, in places of worship, and also in public places, such as terminals, markets, and malls. How to prevent the corona virus suggested by the Indonesian government through the Ministry of Health (Kemenkes) of the Republic of Indonesia to urge the public to prevent the spread of Covid-19 by increasing public behavior and knowledge and implementing a clean and healthy lifestyle. The government asks the public to always apply clean and healthy living behavior every day by:

a) wash your hands frequently with soap

b) wear a mask

c) keep your distance

d) enough rest

e) exercise regularly

f) throw garbage in its place

g) no smoking

h) eat a balanced nutritious diet

i) avoid stress and manage stress

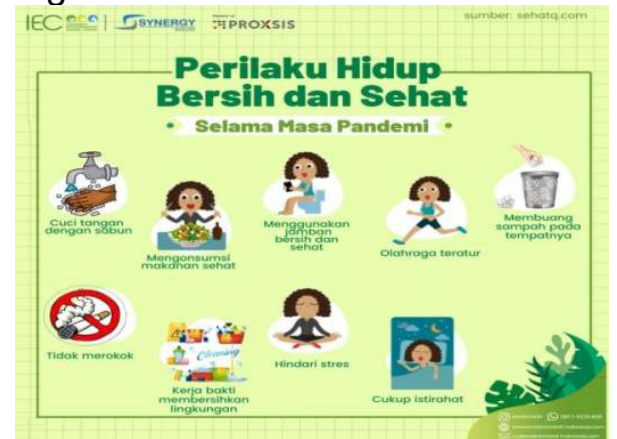

Figure 1. Clean and Healthy Living Behavior During The Pandemic

A healthy body will be very difficult to be infected by various dangerous diseases and viruses such as Covid-19 and other diseases, because a healthy body has a strong defense (immunity) and is easy to heal itself. Therefore, it is very important for the community to establish a Clean 
and Healthy Life Behavior (PHBS) in the family environment and the surrounding community. This pandemic is a common problem and of course must be resolved together by preventing it so that confirmed cases can approach point 0 so that there will be no more spread until Indonesia can finally win against this pandemic.

\section{The importance of the use of masks}

The Covid-19 pandemic caused by the SARS-CoV-2 virus has caused the World Health Organization (WHO) to issue regulations, one of which is the obligation to use masks for all people in public places. The use of this mask as a form of preventing the transmission of Covid19 through droplets. Droplets are liquids that come out of the respiratory tract.

The increasing demand for masks and the scarcity of existing masks have made the government allow the public to use cloth masks. However, the use of cloth masks can prevent the entry and exit of droplets, although not $100 \%$. The use of medical masks that are more effective in preventing the transmission of the virus is recommended for use by medical personnel and people who are sick. The spread of the new variant of the corona virus requires us to be more vigilant and tighten self-protection when outside the home. One that is recommended is to use two masks or a double mask. The recommended use of two masks is a cloth mask and a medical mask. Rules for the use of double masks must be adhered to so that they are truly protected effectively. Just like using masks in the usual way, surgical masks must be covered with cloth masks, while cloth masks can be reused, but must be washed first until they are clean.

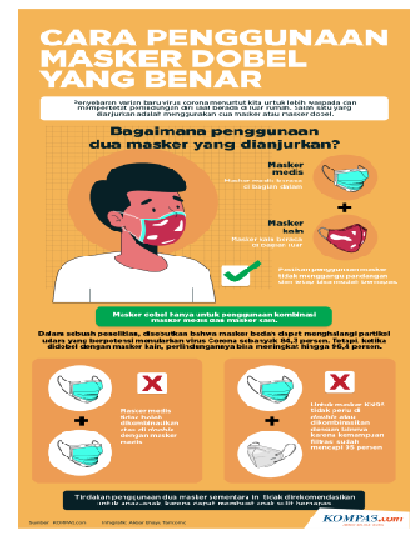

Figure 2. How to use the correct double mask

While wearing a mask we must not touch the front of the mask. Filtered dust, viruses and bacteria stick to the front of the mask. Once the mask is dirty, feels damp or wet, it should be replaced immediately. Ideally the mask should be changed every 4 hours. The mask is removed by removing the hooks attached to the ears. Cloth masks that have been used are recommended to be soaked in warm water which is then washed with detergent so that the viruses and bacteria contained in the masks die. After the mask is removed, hands are washed again using soap and running water or hand sanitizer.

Based on the results of field observations that are tailored to the needs and potential of the village, the realization of the action plan carried out is as follows

\section{- Socialization and Training on Making Cloth Masks}

The lack of awareness and ownership of the community towards masks in carrying out daily activities is a factor that causes the importance of this program to be carried out. One of the ways to prevent the spread of COVID-19 is to wear a mask. The manufacture of cloth masks can be used or traded to increase the economy during the pandemic. PHBS socialization about the importance of using masks and training in making masks are expected to make people more aware of the importance of using masks.

Materials for non-medical masks (fabric) should include the following three layers: 1) an innermost layer made of a hydrophilic material (such as cotton or cotton blends); 2) an outer layer made of a hydrophobic material (such as polypropylene, polyester, or a mixture of both) which can limit contamination from outside penetrating into the wearer's nose and mouth; 3) a 
hydrophobic middle layer made of a synthetic non-woven material such as polypropylene or cotton lining that can increase filtration or retain droplets.

The minimum number of layers for a cloth mask is three, depending on the fabric used. The innermost layer of the mask touches the wearer's face. The outermost layer is exposed to the environment. Clothing fabrics (eg, a mixture of nylon and $100 \%$ polyester) when folded in two layers provide 2-5 times the filtration efficiency compared to a single layer of the same fabric, and when folded into four layers the filtration efficiency increases by 2-7 times. Masks made of cotton handkerchiefs alone must consist of four layers, but the filtration efficiency is only $13 \%$. Highly porous materials such as gauze will not be able to provide sufficient filtration even if they are made in layers; its filtration efficiency is only $3 \%$.

Masks can be flat-folded or duckbills. The shape of the mask is designed to fit tightly on the nose, cheeks, and chin of the wearer. When the edge of the mask does not close tightly to the face and shifts, for example when speaking, air from inside/outside penetrates through the edge of the mask and is not filtered through the mask cloth. Air leaks in and out without being filtered can be caused by the size and shape of the mask. The manufacture of cloth masks begins with preparing tools and materials in the form of:

a) Tools

Scissors

- hand needle

- pins

- Used cardboard or cardboard

- Yarn

- Bonding rubber

b) Material

- Patterned cotton fabric

The use of cloth masks is different from medical masks, which can only be used for up to 4 hours, after which they are immediately washed and replaced with new cloth masks. The advantage of this mask is that the material is easy to obtain and affordable in terms of cost.

Socialization regarding the use of cloth masks that are recommended as APD needs to be considered so that the use of masks for self-protection is optimal and the spread of the new variant of the corona virus requires us to be more vigilant and tighten self-protection when outside the house. One that is recommended is to use a double mask. Masks are recommended to be used by adults, but not recommended for children because they can make it difficult for children to breathe, by paying attention to the size and proper use so that the function of the mask becomes effective.

\section{The Importance of Washing Hands Or Using Hand Sanitizer}

Washing hands with soap is one of the sanitation measures by cleaning hands and fingers using water and soap by humans to be clean and break the chain of germs. Washing hands with soap (CTPS) is also known as an effort to prevent disease. This is done because hands are often agents that carry germs and cause pathogens to transfer from one person to another, either by direct contact or indirect contact (using other surfaces such as towels, glasses). Hands that are in direct contact with human and animal feces, or other body fluids (such as mucus, and contaminated food/drinks when not washed with soap can transfer bacteria, viruses, and parasites to other people who are not aware that they are being transmitted. These hands are then become an intermediary in disease transmission.

Washing hands with water alone is more common, but this has proven to be ineffective in maintaining health compared to CTPS. Using soap in washing hands actually causes people to have to allocate more time when washing hands, but the use of soap becomes effective because the fat and dirt that sticks will be released when the hands are rubbed and rubbed in an effort to remove them. In the fat and dirt that sticks are living germs. 


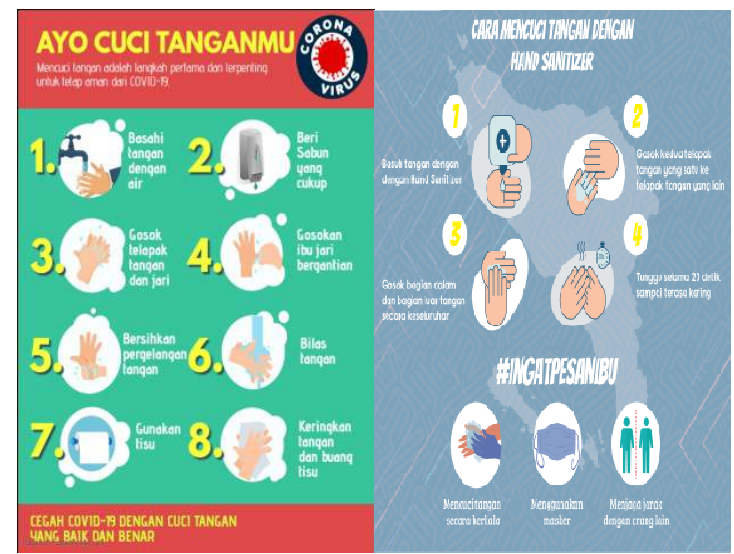

Figure 3. How to wash hands with soap and hand sanitizer

Of course, not all places have clean water, soap, and a sink. Therefore, hand sanitizer can also be an alternative. Always carry a small bottle of hand sanitizer with you and use it after coming into contact with people and objects such as handles on buses or trains, doorknobs, or other objects that are prone to being touched by many people. Use a hand sanitizer with an alcohol content of at least 60 percent or more and can also be made with natural ingredients. But soap and water are recommended because the process is better at killing certain types of germs, including the Covid-19 virus. Especially if our hands are dirty or oily, hand sanitizer will also not clean them effectively. How to use hand sanitizer is quite easy, after spraying on the hands, rub the surface of the hands, fingers, and between the fingers until it dries.

Based on the results of field observations that are tailored to the needs and potential of the village, the realization of the action plan carried out is as follows.

- Socialization and Manufacture of Hand Sanitizers With Natural Ingredients

The lack of public knowledge regarding the use of natural ingredients as antiseptics (hand sanitizers) is the basis for implementing this program. People do not know the efficacy of betel leaf and lime as an antiseptic, so the two types of natural ingredients are only used for cooking and/or treatment purposes.

Prevent various infections and diseases, namely maintaining hand hygiene by regularly washing hands using clean water and soap for approximately 20 seconds under running water. However, there are times when we are traveling or doing activities outside the home so we have difficulty finding a toilet and a place to wash our hands. So the use of hand sanitizer can be one solution to clean hands from germs that stick.

In the manufacture of this hand sanitizer, natural ingredients are used, namely $15 \%$ betel leaf extract and $8 \%$ lime so that this hand sanitizer is very practical and can be made by yourself without incurring expensive costs. The efficacy of $15 \%$ betel leaf extract is as effective as alcohol in killing germs. However, this hand sanitizer does not use alcohol and other preservatives so that the product lasts only 7-14 days. The manufacture of this hand sanitizer begins with preparing tools and materials in the form of:

a) Tools

container

- Stove

- Scissors

- pot

- Sieve

- spray bottle

b) Material

water

- Betel leaf

Socialization regarding the manufacture of hand sanitizers natural ingredients that are easily found in areas around people's residences. Natural hand sanitizer is an alternative way to replace the limited water, soap and avoid using hand sanitizers that contain alcohol and 
chemicals. The advantages of hand sanitizer are natural ingredients and do not use preservatives, so they will not irritate hands and dry skin but can only last for approximately two weeks.

\section{CONCLUSIONS And RECOMMENDATIONS}

The implementation of this Real Work Lecture (KKN) focuses on the community being able to apply the health protocols set by the government regarding the prevention of Covid-19, such as wearing masks when outside the home, washing hands or using hand sanitizers, and maintaining social distance.. Above-mentioned activities carried out in order to increase knowledge, awareness and skills of villagers in Padang Sambian kelod particularly in developing the potential of the village in the middle of a pandemic COVID-19 so as to avoid transmission of the virus COVID-19 and returned to work in the order of life / new habit (new normal life).

The author hopes that the community will form new habits and be able to carry out clean and healthy living behaviors and maintain a clean environment to prevent disease and improve health status. This behavior can be entrenched in society, so it can become a new habit that is not only enforced during this COVID-19 pandemic.

\section{ACKNOWLEDGMENTS}

The successful implementation of community service and preparation of reports, the authors would like to thank all those who have helped carry out this activity including the Universitas Pendidikan Nasional , LP2M Universitas Pendidikan Nasional, Advisory Lecturers, Communities in the village environment of Padang Sambian Kelod and others who could not mentioned one by one.

\section{REFERENCES}

Anindita, D. S. (2020). Sosialisasi Pencegahan Covid-19 Melalui Perilaku Hidup Bersih dan Sehat di Kampung Juku Batu Kecamatan Banjit Kabupaten Way Kanan. Al-Mu'awanah : Jurnal Pengabdian kepada Masyakarat Vol. 1 No. 2 Tahun 2020 , 1, 35-40. http://ejournal.radenintan.ac.id/index.php/ajpm/article/view/8053

Buku Pedoman. (2020) Pentingnya Penggunaan Masker. Dalam Buku Pedoman. Diakses 21 Juli 2021

darihttps://www.kedungpohnglipar.desa.id/assets/files/dokumen/Pentingnya\%20Penggunaa n\%20Masker.pdf

Dinas Kesehatan Provinsi Bali. (2021). Jumlah Terpapar Covid-19 Di Denpasar. Diakses pada 10 Juli 2021 dari https://www.diskes.baliprov.go.id/portfolio/perkembangan-penyebaran-viruscoronal

Dinas Kesehatan Provinsi Bali. (2021). Upaya Pencegahan Covid-19. Diakses pada 28 Juli 2021 dari https://www.diskes.baliprov.go.id/ayo-kita-lakukan-cuci-tangan-pakai-sabun-ctpssebagai-salah-satu-upaya-pencegahan-covid19/

Ibrahim, SA. (2020). Laporan Pengabdian Pada Masyarakat : Perilaku Hidup Bersih dan Sehat (PHBS) di Era New Normal. Laporan

Kementerian PUPR RI. (2020). Perilaku Hidup Bersih dan Sehat (PHBS) sebagai Upaya Mencegah Penyebaran COVID-19. Diakses pada 15 Juli 2021 dari http://plpbm.pu.go.id/v2/posts/Perilaku-Hidup-Bersih-dan-Sehat-PHBS-sebagai-Upaya-

Mencegah-Penyebaran-COVID-19

Kemkes. (2016). Perilaku Hidup Bersih dan Sehat (PHBS). Diakses pada 23 Juli 2021 dari https://promkes.kemkes.go.id/phbs

Kompas. (2021). Cara Penggunaan Dua Masker atau Masker Dobel yang Benar. Diakses pada 20 Juli 2021 dari https://www.kompas.com/tren/read/2021/06/24/120500765/carapenggunaan-dua-masker-atau-masker-dobel-yang-benar?page=all

Mulyadi, Laras dkk. (2020). Laporan KKN : Pentingnya Penerapan Phbs Dalam Menghadapi Pandemi Covid-19 di Lingkungan Masyarakat. Diakses pada 18 Juli 2021 dari 
https://kkn.unnes.ac.id/lapkknunnes/32004 3174101004 6 Kelurahan\%20 202009270729 20.pdf

Peraturan Menteri Kesehatan Republik Indonesia Nomor: 2269/MENKES/PER/XI/2011 Tentang Pedoman Pembinaan Perilaku Hidup Bersih dan Sehat (PHBS).

Taringan, Tri. (2020) Laporan Akhir : Sosialisasi Pengembangan Potensi Desa Melalui Perilaku Hidup Bersih dan Sehat Sebagai Upaya Pencegahan Penyebaran Virus Covid-19 Lokasi Desa Tudi Kecamatan Monanp Kabupaten Gorontalo Utara. Laporan.

Wahyuni, I. R. (2021). Edukasi Perilaku Hidup Bersih Dan Sehat (PHBS) Di Masa Adaptasi Kebiasaan Baru Di Kelurahan Kampung Baru Kota Sorong. Jurnal Pengabdian Masyarakat Indonesia (JPMI) , 1, 173-178. https://jpmi.journals.id/index.php/jpmi/article/view/39 


\section{APPENDIX}

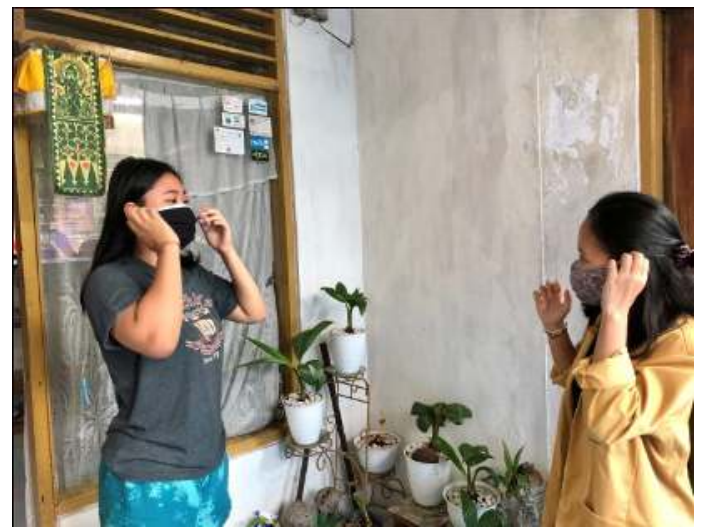

Figure 1. Socialization Of The Use Double Masks
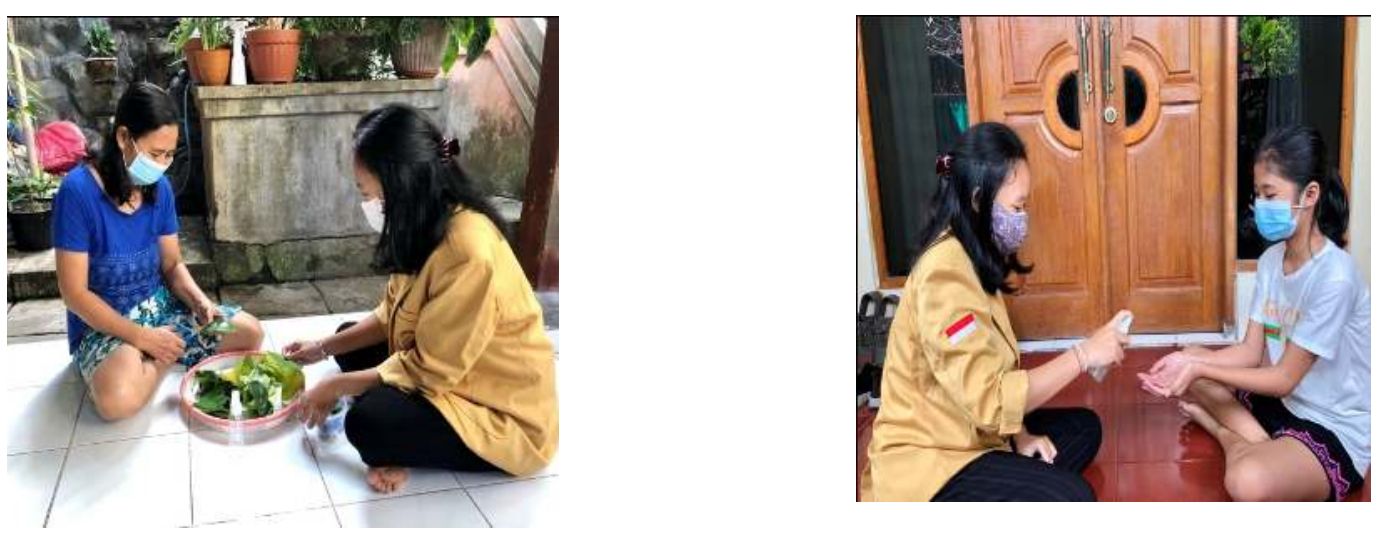

Figure 2. Socialization Of Making Natural Hand Sanitizer 